\title{
The Impact of Systemic Diseases on the Effect of Conservative Periodontal Disease
}

\author{
Saimir Heta, Ilma Robo*, Eduart Kapaj, Sonila Robo, Nevila Alliu \\ Albanian University, Department of Stomatology, Tirana, Albania
}

*Corresponding Author: Ilma Robo, Albanian University, Department of Stomatology, Tirana, Albania.

\begin{abstract}
Aim: Systemic diseases cause well-expressed local effects in the oral mucosa or gingiva. In conditions where these declared patients suffering from systemic diseases undergo conservative periodontal treatment, the expectation in the prognosis of periodontal disease differs specifically to the patient depending on the severity and stage where the systemic disease is located.

The aim of this study is to evaluate the clinical outcomes of non-surgical periodontal therapy specifically for cardiac, diabetic, nephropathic, and gastrointestinal patients.

Materials and Methods: In a total of 206 patients, divided according to the susceptibility of systemic diseases: cardiac patients, diabetic patients, nephropathic patients, gastrointestinal patients. Patients included in the study were divided according to age, gender and socio-health status prior to non-surgical periodontal treatment. The parameters of the response to periodontal therapy were assessed by recording indices before and after treatment.
\end{abstract}

Results: According to the female ratio: male susceptibility to heart disease is 16\%: 23\%, diabetic 19\%: 17\%, nephropathy 17\%: 4\% and gastrointestinal 3\%: 0.5\%. The correlation between cardiac disease: diabetes is $30 \%$ and nephropathy-diabetes is $24 \%$. Pre- and post-treatment survey rates for cardiac patients are $28 \%$ to 45\%; diabetics $30 \%$ to $74 \%$; nephropathies $16 \%$ to $23 \%$ and gastrointestinal $71 \%$ to $100 \%$.

Conclusions: Vulnerability to systemic diseases speaks of high values that combined with susceptibility to periodontal diseases, in relation to the fact that these diseases are related to the aggravation of periodontal diseases expressed in the value of the hemorrhage index. Recovery after non-surgical periodontal therapy is more sensitive in gastrointestinal patients, expressed in high difference in concentration in the values of periodontal sexes, followed by diabetic patients, cardiac patients and then by nephropathies.

Keywords: diabetes, cardiovascular disease, gastrointestinal, nephropathy, periodontal therapy

\section{INTRODUCTION}

The destructive and reconstructive nature of some of the periodontal diseases orients the nonsurgical periodontal treatment in the preservation of the periodontal structures to the level where the periodontal disease has expressed the destructive effect. Oral bacterial flora strikes periodontal structures through destructive products in order to create the right environment for survival, while macrophages, immune markers must react to attack, but within the body's limits it generally allows, based on systemic disease. from which the patient suffers. $(1,2)$

Control of systemic diseases affects the level of the immune system in the body's response during the healing process. These elements affect the reaction of periodontal tissue after the intervention of non-surgical periodontal therapy. The results of non-surgical periodontal therapy are measurable and clinically controllable, and are even assessed as different stages of aggravation, or improvement of systemic disease. (3-7)

Clinical examination of the gingiva, measurement of the depth of the gingival sulcus, gingival hemorrhage index, supplemented by radiographic examination are some of the elements that can be used to establish the diagnosis of current periodontopathy. (8-12)

The aim of this study is to evaluate the clinical outcomes of non-surgical periodontal therapy 
specifically for cardiac, diabetic, nephropathic, and gastrointestinal patients. The clinical presentation of the diseases from which these patients suffer is accompanied by the collection of results according to the indices selected before treatment and 1 week of non-surgical periodontal port treatment.

In the systemic systemic diseases, heart disease, diabetes, hypertension and gastrointestinal diseases are selected, always focusing on the fact that these diseases have a typical clinical picture of the patient's oral cavity for a long time, therefore, depending on the time. diseases have appeared in the oral cavity. (1)

Selected systemic diseases specifically express the clinical picture of the oral cavity and despite the stable protocol of oral therapy, affect wound healing and the duration of full periodontal healing. To achieve the ultimate goal, nonsurgical periodontal therapy for these patients has stages of treatment protocol with the aim of protecting the periodontal tissue at the achieved level of periodontal tissue destruction. (13-15)

\section{Materials AND Methods}

Patients in the study were aware that suffering from systemic diseases selected complemented the purpose of the study. This group of diseases included heart disease, gastrointestinal disease, kidney disease and diabetes. Each patient

Table1. Table 1 shows the distribution of patients in the male-to-female ratio, according to heart disease, diabetes, nephropathy, and gastrointestinal disease.

\begin{tabular}{|c|c|c|c|c|}
\hline Patients & Cardiac Patients & Diabetic Patients & Nephropathy Patients & Gastrointestinal Patients \\
\hline Female & $16 \%$ & $19 \%$ & $17 \%$ & $3 \%$ \\
\hline Male & $23 \%$ & $17 \%$ & $4 \%$ & $0.5 \%$ \\
\hline Total & $39 \%$ & $37 \%$ & $21 \%$ & $3.3 \%$ \\
\hline
\end{tabular}

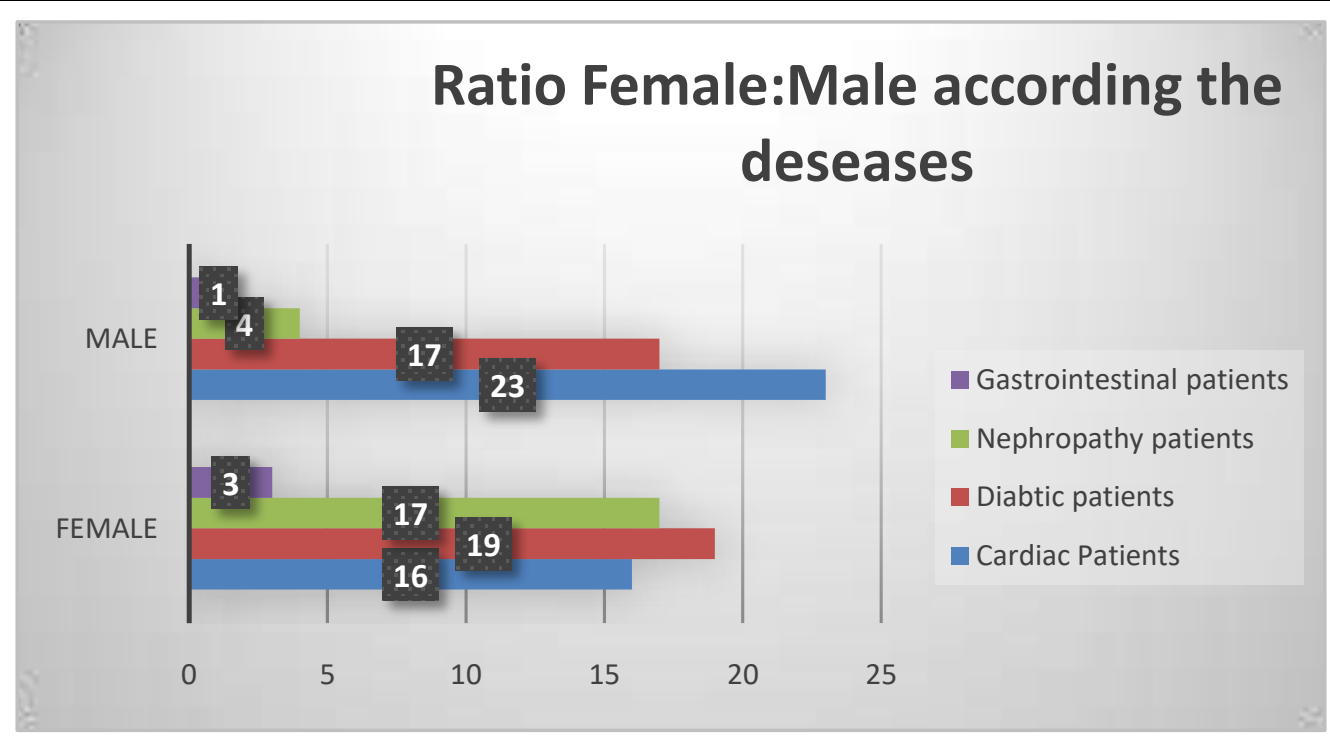

Graph1. Graph 1 shows the distribution of patients in \% according to the male ratio: female, according to heart disease, diabetes, nephropathy and gastrointestinal. 
The Impact of Systemic Diseases on the Effect of Conservative Periodontal Disease

Table2. The relationship between heart disease-diabetes and nephropathy-diabetes

\begin{tabular}{|l|l|l|l|l|l|}
\hline Patients & Cardiac-diabetic Patients & $\%$ & Nephropathy-diabetic Patients & $\%$ & No.- $\%$ \\
\hline Female & 38 & $19 \%$ & 16 & $17 \%$ & $54-26 \%$ \\
\hline Male & 22 & $11 \%$ & 7 & $7 \%$ & $29-14 \%$ \\
\hline Total & 60 & $30 \%$ & 23 & $24 \%$ & $83-40 \%$ \\
\hline
\end{tabular}

Table3. Values of the probing for cardiac, diabetic, nephropathic and gastrointestinal patients before treatment

\begin{tabular}{|l|l|l|l|l|l|l|}
\hline Probing value & \multicolumn{1}{|c|}{$\begin{array}{c}\text { Cardiac } \\
\text { Patients }\end{array}$} & Diabetic Patients & $\begin{array}{c}\text { Nefropathy } \\
\text { Patients }\end{array}$ & $\begin{array}{c}\text { Gastrointestinal } \\
\text { Patients }\end{array}$ & Total & $\%$ \\
\hline Healthy & $22-28 \%$ & $23-30 \%$ & $7-16 \%$ & $5-71 \%$ & 57 & $28 \%$ \\
\hline Ill & $58-73 \%$ & $53-70 \%$ & $36-84 \%$ & $2-29 \%$ & 147 & $71 \%$ \\
\hline Total & $80-39 \%$ & $76-36 \%$ & $4321 \%$ & $7-3 \%$ & 206 & $100 \%$ \\
\hline
\end{tabular}

Table4. Survey values for cardiac, diabetic, nephropathic and gastrointestinal patients after treatment

\begin{tabular}{|l|l|l|l|l|l|l|}
\hline $\begin{array}{l}\text { Probing } \\
\text { value }\end{array}$ & $\begin{array}{l}\text { Cardiac } \\
\text { Patients }\end{array}$ & Diabetic Patients & Nefropathy Patients & $\begin{array}{l}\text { Gastrointestinal } \\
\text { Patients }\end{array}$ & Total & $\%$ \\
\hline Healthy & $36-45 \%$ & $56-74 \%$ & $10-23 \%$ & $7-100 \%$ & 107 & $53 \%$ \\
\hline Ill & $44-55 \%$ & $20-26 \%$ & $33-77 \%$ & $0-0 \%$ & 97 & $47 \%$ \\
\hline Total & $80-39 \%$ & $76-36 \%$ & $43-21 \%$ & $7-3 \%$ & 206 & $100 \%$ \\
\hline
\end{tabular}

\section{Probing value before and after treatment for periodontal patients}

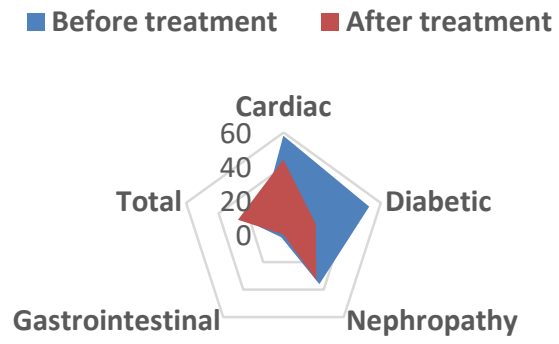

Graph2. Probing value for cardiac, diabetic, nephropathic and gastrointestinal patients, before and after treatment for periodontal patients

\section{Probing values before and after treatment for periodontal healthy patients}

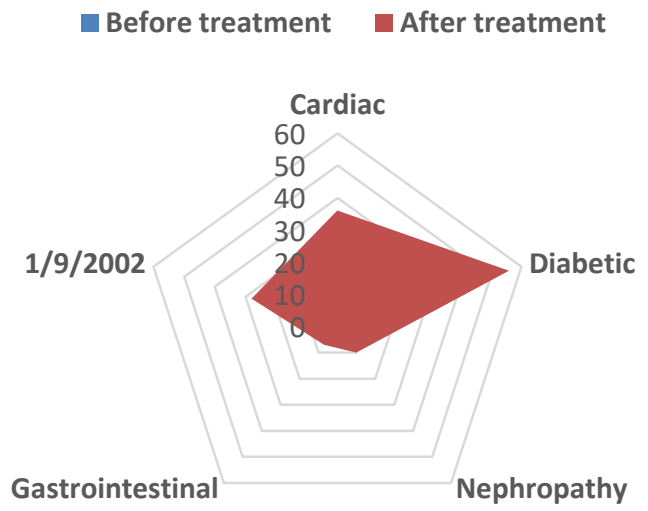

Graph3. Probing values for cardiac, diabetic, nephropathic and gastrointestinal patients, before and after treatment for periodontal healthy patients 
Table5. Values of the hemorrhage index for cardiac, diabetic, nephropathic, gastrointestinal patients

\begin{tabular}{|l|l|l|}
\hline Values of the hemorrhage index & Before treatment & After treatment \\
\hline Cardiac & $42 \%$ & $39.5 \%$ \\
\hline Diabetic & $45 \%$ & $13 \%$ \\
\hline Nephropathy & $37 \%$ & $35.5 \%$ \\
\hline Gastrointestinal & $32 \%$ & $5 \%$ \\
\hline
\end{tabular}

The association of heart disease and periodontal disease is already well-known based on the data published in the literature. There are many articles published about the impact of chronic periodontitis on blood fibrinogen levels and as a result can lead to arteriosclerosis. Activation of macrophages in arteriosclerotic plaques. Cardiac disease is thought to be associated with periodontal disease aggravation is hypertension, which affects periodontal tissue more with the effects of the medications the patient is being treated with. 16-19) Hypertrophy by calcioblockers is prone to signs of gingival tissue fibrotization. (20-25) Cholesterol levels associated with fibrinogen fluctuations in the blood are two elements that affect the appearance of arteriosclerosis plaques. (25-32) There are studies that highlight the link between blood cholesterol levels and increased pocket depth in patients with arteriosclerosis. (33-35) But again, blood cholesterol levels are associated with increased pocket depth. in control group patients. (36)

Diabetes shows its effect on oral cavities compared to increasing the amount of glucose in saliva and gingival fluid. The increase in glucose in the oral cavity is affected by the lack of control of blood glucose levels. By having high amounts of glucose in saliva, the possibility of bacterial plaque formation in the gingival margins increases. Diabetic patients have a higher $\mathrm{pH}$ of the oral cavity in terms of acid than patients who do not suffer from these systemic diseases. In diabetic patients, the delay in wound healing is always noticeable. This delay is explained by the slow movement of neutrophils toward the inflamed areas, as it is known that the first stage of healing is the phase of clearing the area of neutrophils that perform the phagocytosis of any undesirable element in the wound.

Recent studies point out that, from the data collected, patients suffering from type I diabetes mellitus are more affected by periodontal disease and tooth loss, and that such problems increase over the years and with age. (37)

Kidney disease affects the excretion of harmful elements, which in the case of normalcy should be filtered by the kidneys themselves. Patients with gastrointestinal problems are associated with the treatment of periodontal disease at the point of caution when prescribing certain medications, as their absorption is affected by medications taken to treat gastrointestinal diseases, keeping stomach acid under $\mathrm{pH}$ control.

\section{CONClusions}

Vulnerability to systemic diseases speaks of high values combined with susceptibility to periodontal disease, in relation to these diseases there is talk of aggravation of periodontal diseases expressed in the value of the hemorrhage index. Healing after non-surgical periodontal therapy is most sensitive in gastrointestinal patients, expressed in high difference in concentration in the values of periodontal sexes, followed by diabetic patients, cardiac and then by nephropathies.

\section{REFERENCES}

[1] Michael G.Newman, DDS, Henry H.Takey, DDS, Ms.FerminA.Carranza, Dr.Odont; "Clinical Periodontology; Ninth edition"; 2004 Mosby.

[2] W. J. Teeuw, D. E. Slot, H. Susanto et al., "Treatment of periodontitis improves the atherosclerotic profile: a systematic review and meta-analysis," Journal of Clinical Periodontology, vol. 41, no. 1, pp. 70-79, 2014.

[3] JirinaBartova, PavlaSommerova, Yelena Lyuya-Mi, Jaroslav Mysak, JarmilaProchazkova, Jana Duskova, Tatjana Janatova, and Stepan Podzimek; "Periodontitis as a Risk Factor of Atherosclerosis"; Journal of Immunology Research;Volume 2014, Article ID 636893, 9 pages http://dx.doi.org/10.1155/2014/636893.

[4] Goodson JM.; “Antimicrobial strategies for treatment of periodontal diseases"; Periodontol 2000. 1994;5:142-68. [PubMed].

[5] Slots J, Rams TE; “Antibiotics in Periodontal therapy: Advantages and disadvantages"; J Clin Periodontol. 1990;17:479-93. [PubMed].

[6] Sakkelari D, Goodson JM, Kolokotronis A.; "Concentration of 3 tetracyclines in plasma, GCF and Saliva'; J Clin Periodontol. 2000;27:53-60. [PubMed]. 
[7] Vidal F, Figueredo CM, Cordovil I, Fischer $\mathrm{RG}$; "Periodontal therapy reduces plasma levels of interleukin-6, C-reactive protein, and fibrinogen in patients with severe periodontitis and refractory arterial hypertension"; J Periodontol. 2009 May; 80(5):786-91. doi: 10.1902/jop.2009.080471.

[8] Hussain M, Stover CM, Dupont A; "P. gingivalis in Periodontal Disease and Atherosclerosis - Scenes of Action for Antimicrobial Peptides and Complement"; Front Immunol. 2015 Feb 10;6:45. doi: 10.3389/fimmu.2015.00045. eCollection 2015.

[9] Mackie IJ, Kitchen S, Machin SJ, Lowe GD; "Haemostais and Thrombosis Task Force of the British Committee for standards in Haematology. Guidelines for fibrinogen assays"; Br J Haemotol2003;121:396-304.

[10] American Diabetes Association. Standards of medical care in diabetes. Diabetes Care 2009; 32:S13-61.

[11] DiagnozaOrale, pjesa e parë, Steveen L. Bricker, Robert P. Langlais, Craig S. Miller. Kapitulli "Çrregullimetendokrine" fq.470-481.

[12] MjekësiaOrale, Mealey, DDS, MS kapitulli "Diabeti Mellitus", fq. 651-665.

[13] Idf Diabetes Atlas, seventh edition, executive summary, 2015.

[14] http://www.diabeti-shqip.org.

[15] Ahmed N.; "Advanced glycation endproductsrole in pathology of diabetic complications"; Diabetes Res Clin Pract 2005; 67:3-21.

[16] Ref: Interactions between chronic renal disease and periodontal disease; Craig RG oral dis 2008; $14: 1-7$

[17] Tom D Daley, DDS MSc FRCDC1 and Jerrold E Armstrong, DDS MSc FRCDC; "Oral manifestations of gastrointestinal diseases"; Can J Gastroenterol.; 2007 Apr; 21(4): 241244; PMCID: PMC2657699; PMID: 17431513.

[18] Moazzez R, Bartlett D, Anggiansah A. Dental erosion, gastrooesophageal reflux disease and saliva: How are they related? J Dent. 2004;32:489-94. [PubMed].

[19] Barron RP, Carmichael RP, Marcon MA, Sandor GK. Dental erosion in gastroesophageal reflux disease. J Can Dent Assoc. 2003;69:849. [PubMed].

[20] Little JW. Eating disorders: Dental implications. Oral Surg Oral Med Oral Pathol Oral RadiolEndod. 2002;93:138-43. [PubMed]

[21] Kumar V, Fausto N, Abbas A. Robbins and Cotran's Pathologic Basis of Disease. 7th edn. Philadelphia: Elsevier Saunders; 2005.

[22] Neville BW, Damm DD, Allen CM, Bouquot JE. Oral \& Maxillofacial Pathology. 2nd edn. Philadelphia: WB Saunders; 2002.
[23] Bohmer T, Mowe M. The association between atrophic glossitis and protein-calorie malnutrition in old age. Age Ageing. 2000;29:47-50. [PubMed].

[24] Drinka PJ, Langer E, Scott L, Morrow F. Laboratory measurements of nutritional status as correlates of atrophic glossitis. J Gen Intern Med. 1991;6:137-40. [PubMed].

[25] Field EA, Speechley JA, Rugman FR, Varga E, Tyldesley WR. Oral signs and symptoms in patients with undiagnosed B12 deficiency. J Oral Pathol Med. 1995;24:468-70. [PubMed].

[26] Chaudhry SI, Philpot NS, Odell EW, Challacombe SJ, Shirlaw PJ. Pyostomatitisvegetans associated with asymptomatic ulcerative colitis: A case report. Oral Surg Oral Med Oral Pathol Oral RadiolEndod. 1999;87:327-30. [PubMed].

[27] Ruiz-Roca JA, Berini-Aytes L, Gay-Escoda C. Pyostomatitisvegetans. Report of two cases and review of the literature. Oral Surg Oral Med Oral Pathol Oral RadiolEndod. 2005;99:44754. [PubMed].

[28] Katz J, Shenkman A, Stavropoulos F, Melzer E. Oral signs and symptoms in relation to disease activity and site of involvement in patients with inflammatory bowel disease. Oral Dis. 2003;9:34-40. [PubMed].

[29] Ranjitkar S, Kaidonis JA, Smales RJ. Gastroesophageal reflux disease and tooth erosion. Int J Dent. 2012;2012:479850. [PMC free article][PubMed].

[30] Silva MA, Damante JH, Stipp AC. Gastroesophageal reflux disease: New oral findings. Oral Surg Oral Med Oral Pathol Oral RadiolEndod. 2001;91:301-10. [PubMed].

[31] Vakil N van ZantenSv, Kahrilas P, Dent J, Jones R, Global Consensus Group. The Montreal definition and classification of gastroesophageal reflux disease: a global evidence-based consensus. Am J Gastroenterol. 2006;101:1900-20. [PubMed].

[32] Pace F, Pallotta S, Tonini M, Vakil N, Bianchi Porro G. Systematic review: gastrooesophageal reflux disease and dental lesions. Aliment PharmacolTher. 2008;27:1179-86. [PubMed].

[33] Vinesh E, Masthan K, Kumar MS, Jeyapriya SM, Babu A, Thinakaran M. A Clinicopathologic Study of Oral Changes in Gastroesophageal Reflux Disease, Gastritis, and Ulcerative Colitis. J Contemp Dent Pract. 2016;17:943-7. [PubMed].

[34] Corrêa MC, Lerco MM, Henry MA. Study in oral cavity alterations in patients with gastroesophageal reflux disease. Arq Gastroenterol. 2008;45:132-6. [PubMed]. 
[35] Talley N. Self-reported Halitosis and Gastroesophageal Reflux Disease in the General Population. J Gen Intern Med. 2008;23:260-6. [PMC free article][PubMed].

[36] Rosy Valensia, Sri Lelyati C. Masulili, Robert Lessang, BasuniRadi; "Association between blood cholesterol level with periodontal status of coronary heart disease patients"; Published Online: 21 February 2017; AIP Conference
Proceedings $\quad 1817, \quad 030006$ https://doi.org/10.1063/1.4976775.

(2017);

[37] Rokhsareh Sadeghi, Ferial Taleghani,Samira Mohammadi, Zahra Zohri; "The Effect of Diabetes Mellitus Type I on Periodontal and Dental Status"; J Clin Diagn Res. 2017 Jul; 11(7): ZC14-ZC17.; Published online 2017 Jul 1. doi: 10.7860/JCDR/2017/25742.10153; PMCID: PMC5583944; PMID: 28893034

Citation: Saimir Heta, Ilma Robo, Eduart Kapaj, Sonila Robo, Nevila Alliu. The Impact of Systemic Diseases on the Effect of Conservative Periodontal Disease. 2020; 5(1):15-20. DOI: https://doi.org/10.20431/24560030.0501005 .

Copyright: (c) 2020 Authors. This is an open-access article distributed under the terms of the Creative Commons Attribution License, which permits unrestricted use, distribution, and reproduction in any medium, provided the original author and source are credited. 